\title{
Anandamide mitigates ischemia/reperfusion (I/R)-induced gastric ulcer: modulation of inflammation and oxidative stress Shahata H. ${ }^{1}$, El-Abhar H. ${ }^{1,2}$, El-Maraghy N. ${ }^{3}$ \\ ${ }^{1}$ Department of Pharmacology \& Toxicology, ${ }^{\text {th }}$ October University ${ }^{2}$ Department of Pharmacology \& Toxicology, Cairo University ${ }^{3}$ Department of Pharmacology\& Toxicology, Future University *Correspondence Author E-mail: dr1983hasan_elheweny@ hotmail.com
}

\begin{abstract}
Anandamide is a cannabinoid receptors agonist that showed a protective effect against intestinal I/R model. However, its modulatory effect on I/R-induced gastric ulcer has not been previously elucidated. Therefore, the aim of this study was to delineate this modulatory effect of anandamide on gastric ulcer and the possible involvement of the liver. Rats were randomized into sham, I/R and anandamide treated group $(1.5 \mu \mathrm{mol} / \mathrm{kg})$. Gastric $\mathrm{I} / \mathrm{R}$ caused an increase in the gastric ulcer index in addition to elevation of the inflammatory mediators TNF- $\alpha$, nuclear factor kappa-B (NF- $\mathrm{B})$, and MPO along with a significant decrease in adenosine monophosphate protein kinase (AMPK) activity; this effect was shown both in the stomach and liver. Moreover, the gastric insult resulted in an imbalance in the redox system, where it elevated the lipid peroxidation content along with a noticeable decrease in the defense system (GSH, CAT and SOD). Additionally, I/R caused a marked increase in the serum activity of the aminotransferases ALT and AST, documenting the involvement of liver injury with gastric I/R model. Preadministration of anandamide proved its anti-inflammatory effect by decreasing the measured inflammatory parameters and increased that of AMPK. Regarding its endowed antioxidant property, anandamide enhanced tissue activity/content of CAT, SOD, as well as GSH, besides normalizing the MDA level. Conclusion: the protective mechanisms of anandamide against I/Rinduced gastric ulcer and liver injury may be mediated by modulation of oxidative stress through the improvement of the endogenous defense system. In addition, the anti-inflammatory effect of anandamide may be facilitated via the AMPK and NF- $\kappa B$ pathways.
\end{abstract}

Key words: Gastric ischemia/reperfusion, anandamide, AMPK, TNF- $\alpha$, NF- $\kappa$ B, MPO, lipid peroxidation, catalase, superoxide dismutase, liver, ALT, AST.

\section{INTRODUCTION}

The gastric ischemia/reperfusion (I/R) insult is one of the major causes of gastric ulcer and this model resembles the myocardial ischemia-reperfusion (I/R) clinically (Cour et al., 2014). The I/Rinduced gastric ulcer is accompanied by overproduction of reactive oxygen species (ROS) (Balk, 2000) resulting in elevation of lipid peroxidation and imbalance in redox defense system (El-Abhar et al., 2003). Moreover, this insult in the gut causes the infiltration of neutrophils (Horie et al.,
1997), as well as the enhancement of proinflammatory mediators, as $\mathrm{TNF} \alpha$, which is a powerful pro-inflammatory cytokine that plays a central role in the pathogenesis of I/R-induced gastric ulceration (Seyyed et al., 2012). Moreover, ample of evidence revealed a close link between the reduced adenosine 5'-monophosphate protein kinase (AMPK) activity and inflammation, which is a crucial regulator of energy metabolic homeostasis at the cellular and organismal survival during stress (Jing et al., 2013). The 
I/R insult suppresses the AMPK level along with the elevation of TNF- $\alpha$ and NF- $\kappa$ B by up-regulating the expression of protein phosphatase 2C, an inhibitor of AMPK signaling (Steinberg et al. 2006; Bai et al., 2010). The liver is the first distant organ affected by the intestinal $\mathrm{I} / \mathrm{R}$ due to its coupled vasculature with the intestine organ (Turnage et al., 1991) an effect that is mirrored by the activation of aminotraferases viz., AST and ALT (Kurabayash et al 2005; Harada et al., 2007; Trocha et al., 2014). Anandamide is cannabinoid receptor agonists derived from the female plant of Cannabis sativa $L$ family Cannabaceae (Green Candy Press 2005; Howlett et al., 2002). It has a potent antiulcerogenic and anti-secretory activity via the activation of the cannabinoid receptor $\mathrm{CB}_{1}$ (Sofia et al., 1978; Coruzzi et al., 1999; Izzo et al., 2001). The present study aimed to assess the possible modulatory effect of anandamide on I/R-induced gastric ulcer. Moreover, the current work assessed the possible effect of the gastric I/R on a distant organ as the liver.

\section{MATERIAL and METHODS}

\section{1-Animal}

Male Wistar rats, weighing 180-220 g (Research Institute of Ophthalmology, Giza, Egypt) were kept on a $12 \mathrm{~h}$ light/dark cycles, constant environmental conditions and were maintained on a proper diet chow and water ad libitum. Prior to experiment ( $24 \mathrm{hrs}$ ) all animals were kept individually in wide mesh bottom cages and deprived of food only. All the surgical processes were performed under urethane anesthesia, and all efforts were made to minimize suffering.

\section{2- Drug}

Anandamide was purchased from SigmaAldrich Chemical Company (MO, USA). All other chemicals and reagents used were of analytical grade. Anandamide $(1.5 \mu \mathrm{mol} / \mathrm{kg}$, i.p) was dissolved in $99 \%$ absolute alcohol $(1 \mathrm{ml})$ and completed with saline to $100 \mathrm{ml}$.

\section{3- Induction of gastric I/R}

The I/R model was performed according to the method previously described by Kotani et al. (2007). Briefly, under urethane anesthesia $(1.25 \mathrm{~g} / \mathrm{kg}$, i.p), the celiac artery was occluded using a small disposable vascular clip to induce ischemia for $30 \mathrm{~min}$; afterwards reperfusion was allowed for 90 min. by declamping the artery.

\section{4- Experimental design}

Rats were divided into 3 groups $(n=7-8)$, where in the first one, animals were anaesthetized and the celiac artery was manipulated only to serve as the shamoperated control group. Animals in the following groups were subjected to I/R; the untreated (second) group was denoted as the positive control (I/R), in which animals received the vehicle, $45 \mathrm{~min}$. before I/R. Rats in the $3^{\text {rd }}$ group received anandamide $(1.5 \mu \mathrm{mol} / \mathrm{kg}$, i.p) $45 \mathrm{~min}$. before the induction of gastric $\mathrm{I} / \mathrm{R}$.

\section{5- Biochemical measurements}

At the end of the reperfusion time, the abdomen was surgically opened and blood was drawn from the inferior vena cava to prepare serum, then animal were then killed and the stomach was excised, opened along the greater curvature, rinsed with ice cold saline and the extent of gross mucosal damage was assessed and calculated as the ulcer index (UI). This parameter was measured and expressed as the sum of ulcer lengths per stomach in mm (Nishida et al., 1998). Consequently, glandular mucosa was homogenized in ice-cold saline to obtain $20 \%$ homogenate using a stainless steel homogenizer (MPW-120, Poland). Moreover, the liver was collected from each rat, weighed and homogenized in ice-cold saline to obtain $20 \%$ homogenate. Different tissues (stomach, intestine, liver, kidney \& 
pancreas) homogenates were kept in aliquotes and stored at $-80{ }^{\circ} \mathrm{C}$ till assessment of biochemical parameters.

\section{1- Estimation of serum parameters}

The serum level of the following parameters was evaluated using the corresponding kits and the catalogue number as shown in parentheses. AST and ALT (Teco diagnostics, CA, USA), serum TNF- $\alpha$ (Koma Biotech, seoul, Korea), NF- $\kappa \mathrm{B}$ (EIAab, Wuhan, China) and serum AMPK (Abcam, Cambridge, UK).

\subsection{Estimation of tissue parameters}

\subsubsection{Estimation of the activity of meyaloperoxidase (MPO)}

MPO (U/gm), a marker for tissue neutrophil infiltration, was assessed according to Bradley et al. (1982). The method is based upon measuring the hydrogen peroxidedependent oxidation of o-dianisidine, catalyzed by MPO, which results in the formation of a compound exhibiting an increased absorbance at $460 \mathrm{~nm}$.

\subsubsection{Estimation of malondialdehyde (MDA)}

Lipid peroxidation (nmol/g tissue) was determined according to the method of Mihara and Uchiyama (1978), where the thiobarbituric acid reactive substances (TBARS), measured as malondialdehyde (MDA), was used as an index of lipid peroxides. The MDA-TBA adduct develops pink color, which was extracted by n-butanol and measured at two wave lengths, viz., 520 and $535 \mathrm{~nm}$.

\subsubsection{Estimation of reduced glutathione (GSH)}

The method described by Ahmed et al. (1991) was adopted to assess the gastric nonprotein sulfhydryl groups (mainly GSH) by reacting with Ellman's reagent after precipitation of protein $\mathrm{SH}$-groups. The reaction with Ellman's reagent forms a stable yellow color of 5 mercapto-2nitrobenzoic acid, which was measured colorimetrically at $412 \mathrm{~nm}(\mathrm{mg} / \mathrm{gm})$.

\subsubsection{Estimation of superoxide dismutase (SOD)}

SOD activity was determined in the cytosolic fraction of the stomach homogenate according to method of Marklund \& Marklund (1974). It depends on that the spontaneous autoxidation of pyrogallol, at alkaline $\mathrm{pH}$, produces superoxide anion radical $\left(\mathrm{O}_{2}{ }^{\circ}\right)$, which in turn enhances more pyrogallol oxidation. The presence of SOD in the reaction medium inhibits pyrogallol autoxidation by scavenging the superoxide anion radical.

\subsubsection{Estimation of catalase (CAT)}

This enzyme was assessed using ELISA colorimetric kit catalase (EIAab, Wuhan, China) as the manufacturer instructions.

\section{Statistical analysis}

Data were expressed as mean \pm S.E.M of 7-8 animals. Statistical comparisons between means were carried out using one-way analysis of variance (ANOVA), followed by Student-Newman-Keuls test. Statistical significance of difference was considered at $P<0.05$.

\section{RESULTS}

\section{1- Effects on oxidative stress}

As depicted in figure 1, ischemia/ reperfusion insult induced in (A) the stomach elevated lipid peroxides level to reach 2.2 folds compared to the sham control group. The same effect was observed in (B) the remote organ; viz., liver; this elevation was mounted to $166 \%$, as compared to the corresponding sham control group. Pretreatment with anandamide, $45 \mathrm{~min}$ (Agurell, 1986) before I/R, has significantly $\mathrm{p}<0.05$ hampered the elevated MDA level in gastric tissue $(86 \%)$ and liver $(35 \%)$ as compared to the I/R group. 


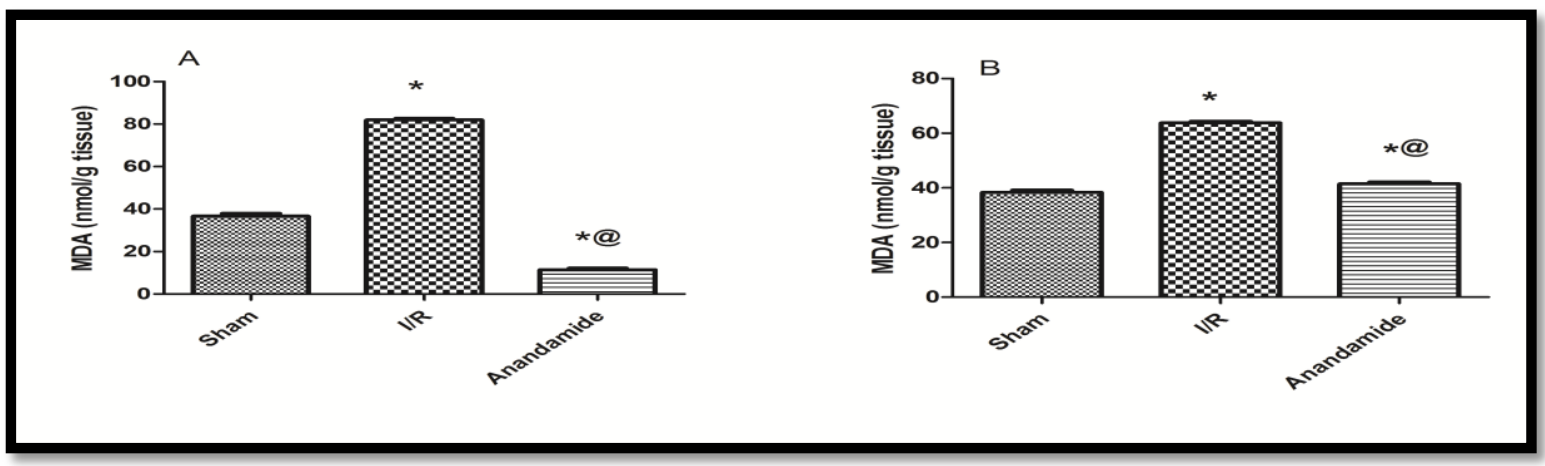

Figure (1): Effect of $30 \mathrm{~min}$. pre-administration of anandamide $(0.4 \mathrm{ml} / \mathrm{kg}$, i.p) on MDA content in (A) stomach and (B) liver of rats subjected to ischemia/reperfusion (I/R; 30/90 min.). Values are expressed as mean \pm SEM ( $n=8$ animals). Statistical analysis was carried out using one way ANOVA followed by Tukey's test for multiple comparisons. Significantly different from sham $(*)$ and $\mathrm{I} / \mathrm{R}\left({ }^{\circledR}\right)$ control groups, $\mathrm{P}<0.05$.

Induction of I/R insult to stomach organ, inhibited one of the enzymatic defense system, SOD. In the (A) gastric tissue the SOD content significantly $\mathrm{p}<0.05$ subsided by $51 \%$ as compared to the sham value. Similarly, SOD content was abated in the (B) liver to reach $24.6 \mathrm{U} / \mathrm{mg}$ proteins vs 83.8U/ $\mathrm{mg}$ in the corresponding sham group. All these altered values were significantly $\mathrm{p}<0.05$ opposed in the anandamide pretreated group as illustrated in figure 2.
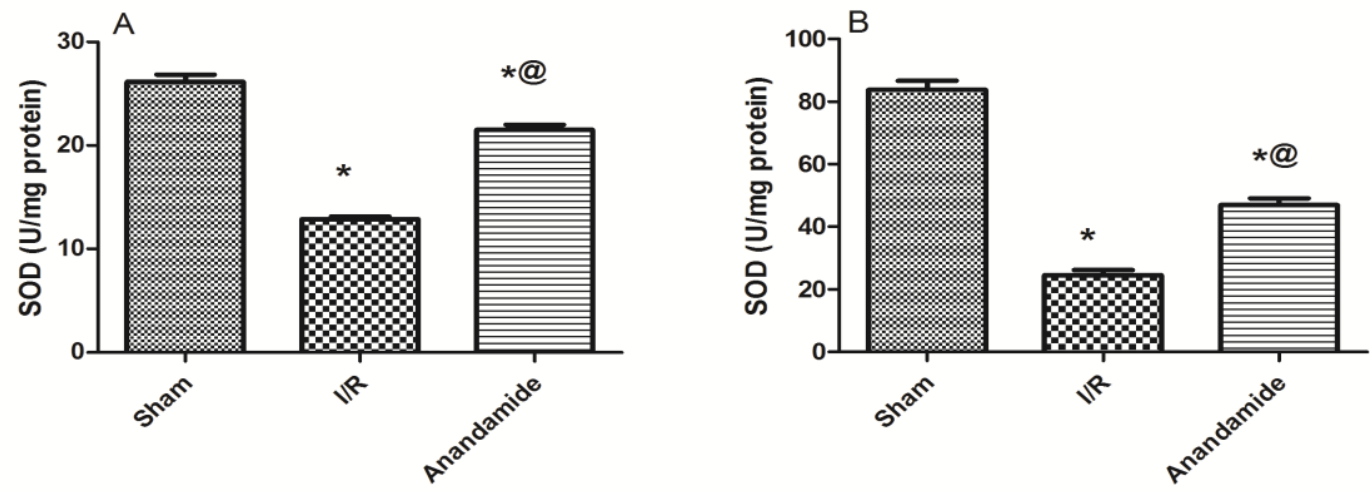

Figure (2): Effect of $30 \mathrm{~min}$. pre-administration of anandamide $(0.4 \mathrm{ml} / \mathrm{kg}$, i.p) on SOD content in (A) stomach and (B) liver of rats subjected to ischemia/reperfusion (I/R; 30/90 min.). Values are expressed as mean \pm SEM ( $n=8$ animals). Statistical analysis was carried out using one way ANOVA followed by Tukey's test for multiple comparisons. Significantly different from sham $(*)$ and I/R $\left({ }^{@}\right)$ control groups, $P<0.05$.

The amount of the CAT enzyme was also evaluated as another anti-oxidant enzyme in both organs; after I/R mediated in the stomach, the insult leveled off the gastric CAT content, as well as the other remote organ, liver. Prophylactic treatment with anandamide before $\mathrm{I} / \mathrm{R}$ induction restored the level of CAT by $64 \%$ in the stomach and $83.4 \%$ in the liver as seen in figure 3 . 


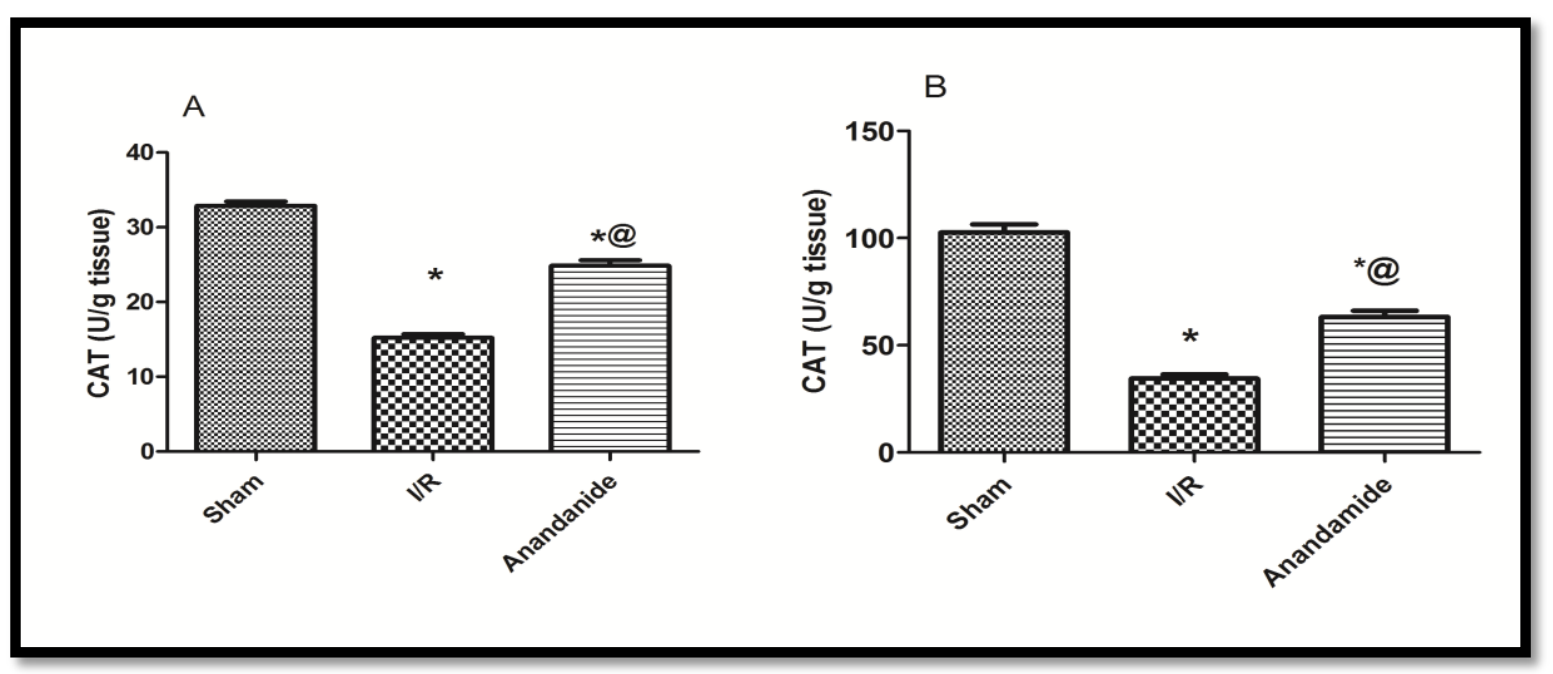

Figure (3): Effect of $30 \mathrm{~min}$. pre-administration of anandamide $(0.4 \mathrm{ml} / \mathrm{kg}$, i.p) on CAT content in (A) stomach and (B) liver of rats subjected to ischemia/reperfusion (I/R; 30/90 min.) Values are expressed as mean \pm SEM ( $n=8$ animals). Statistical analysis was carried out using one way ANOVA followed by Tukey's test for multiple comparisons. Significantly different from sham $(*)$ and I/R $\left({ }^{\circledR}\right)$ control groups, $P<0.05$.

One of the non-enzymatic defense systems is GSH was evaluated in gastric mucosa and liver after I/R insult. The GSH content in the stomach was significantly $\mathrm{p}<0.05$ inhibited by $20 \%$ in the I/R group; alike the effect on the stomach, I/R sharply lowered the GSH content in the liver (84\%), as compared to the normal sham group. The I/R-induced alteration in GSH level was significantly $\mathrm{p}<0.05$ hindered by the prophylactic injection of anandamide as depicted in figure 4.
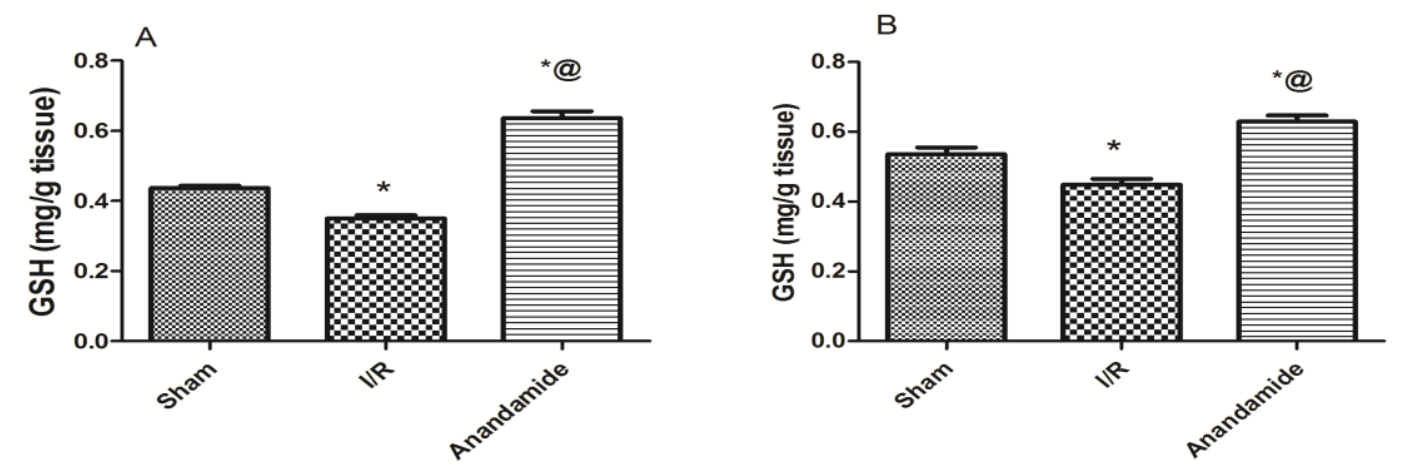

Figure (4): Effect of $30 \mathrm{~min}$. pre-administration of anandamide $(0.4 \mathrm{ml} / \mathrm{kg}$, i.p) on GSH content in (A) stomach and (B) liver of rats subjected to ischemia/reperfusion (I/R; 30/90 min.). Values are expressed as mean \pm SEM ( $n=8$ animals). Statistical analysis was carried out using one way ANOVA followed by Tukey's test for multiple comparisons. Significantly different from sham $(*)$ and I/R $\left({ }^{@}\right)$ control groups, $P<0.05$.

\section{2- Effect on neutrophil infiltration}

The I/R effect on the tested organs boosted the infiltration of neutrophils intracellularly, as manifested by the significant rise in the MPO level. The intraperitoneal administration of anandamide guarded against the I/R effect; in the stomach and liver, the MPO activity was significantly $\mathrm{p}<0.05$ limited 


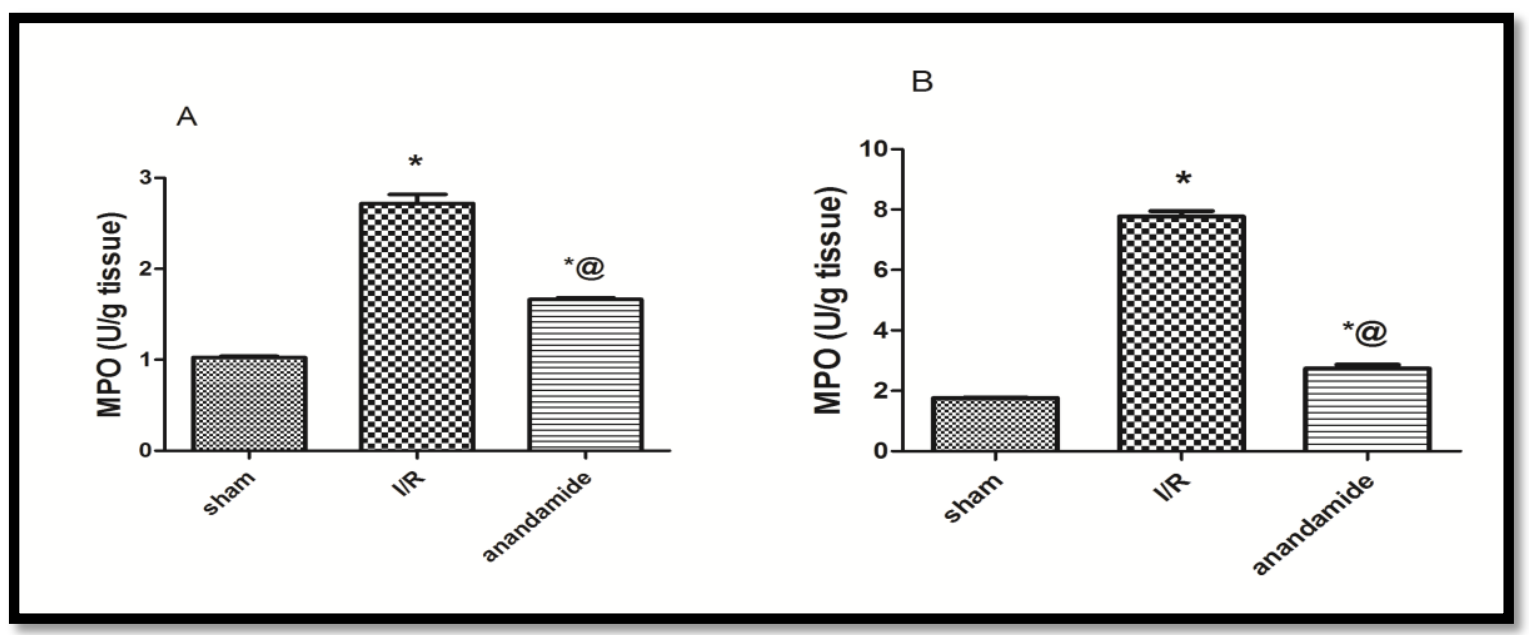

Figure (5): Effect of 30 min. pre-administration of anandamide (0.4 ml/kg, i.p) on MPO content in (A) stomach and (B) liver of rats subjected to ischemia/reperfusion (I/R; 30/90 min.). Values are expressed as mean $\pm \mathrm{SEM}(\mathrm{n}=8$ animals). Statistical analysis was carried out using one way ANOVA followed by Tukey's test for multiple comparisons. Significantly different from sham $(*)$ and I/R $\left({ }^{\circledR}\right)$ control groups, $P<0.05$.

\section{3- Effect on pro-inflammatory mediators}

Following the induction of $\mathrm{I} / \mathrm{R}$ insult the serum TNF- $\alpha$ level was boosted to be around 4 times higher than the sham group, as a consequent to the inflammatory cascade. Pretreatment with anandamide significantly $\mathrm{p}$ $<0.05$ evoked a noticeable protection against the $\mathrm{I} / \mathrm{R}$ insult (Fig. 6). By inspecting the serum content of NF-kB, the insult induced by $\mathrm{I} / \mathrm{R}$ on stomach and liver significantly $\mathrm{p}$ $<0.05$ augmented the level of the proinflammatory mediator by 4 folds in comparison with sham group, while by the pre-treatment with anandamide, the harmful effect of $\mathrm{I} / \mathrm{R}$ has been significantly $\mathrm{p}<0.05$ halved.

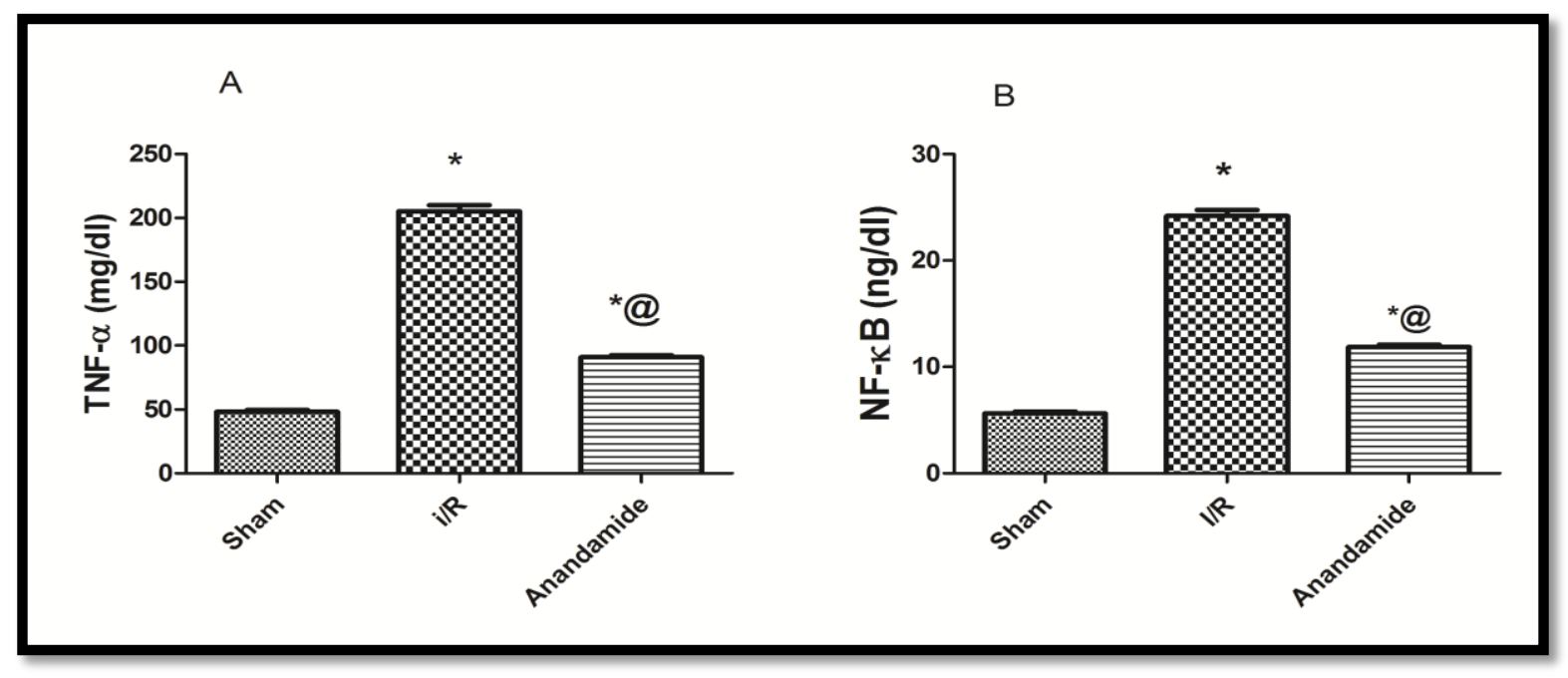

Figure (6): Effect of 30 min. pre-administration of anandamide $(0.4 \mathrm{ml} / \mathrm{kg}$, i.p) on (A) serum TNF $\alpha$ and (B) NF- $\kappa B$ levels in rat subjected to ischemia/reperfusion (I/R; 30/90 min.). Values are expressed as mean \pm SEM ( $\mathrm{n}=8$ animals). Statistical analysis was carried out using one way ANOVA followed by Tukey's test for multiple comparisons. Significantly different from sham $(*)$ and I/R $\left({ }^{@}\right)$ control groups, $P<0.05$. 
4- Effect on serum adenosine 5'monophosphate protein kinase (AMPK)

AMPK acts as an inhibitor of the inflammatory mediators signaling. However, its level was significantly $\mathrm{p}<0.05$ increased by $\mathrm{I} / \mathrm{R}$ to reach to 1.5 fold compared to sham group. The pre-administration of anandamide significantly $\mathrm{p}<0.05$ elevated it further to reach 3.6 times that of the sham control rats and 2.4 folds of the I/R group (Fig. 7).

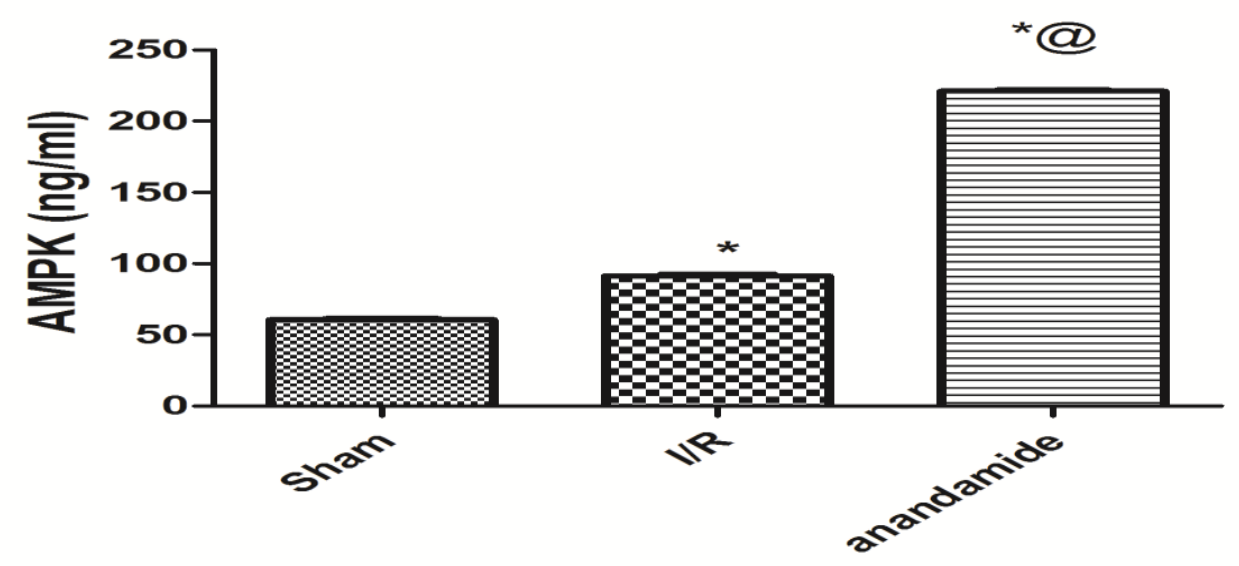

Figure (7): Effect of $30 \mathrm{~min}$. pre-administration of anandamide $(0.4 \mathrm{ml} / \mathrm{kg}$, i.p) on serum AMPK activity of rats subjected to ischemia/reperfusion (I/R; 30/90 min.). Values are expressed as mean $\pm \mathrm{SEM}$ ( $\mathrm{n}=8$ animals). Statistical analysis was carried out using one way ANOVA followed by Tukey's test for multiple comparisons. Significantly different from sham $(*)$ and I/R $\left({ }^{@}\right)$ control groups, $P<0.05$.

\section{5- Effect on liver function}

As depicted in figure 8, (A) the activity of ALT and (B) AST enzymes showed a significant surge caused by I/R; this activation was 2 and 2.6 folds that of the sham values. However, the anandamide pretreated group significantly $\mathrm{p}<0.05$ leveled off ALT and AST by $47 \%$ and $45.4 \%$, respectively, compared to the $\mathrm{I} / \mathrm{R}$ group.

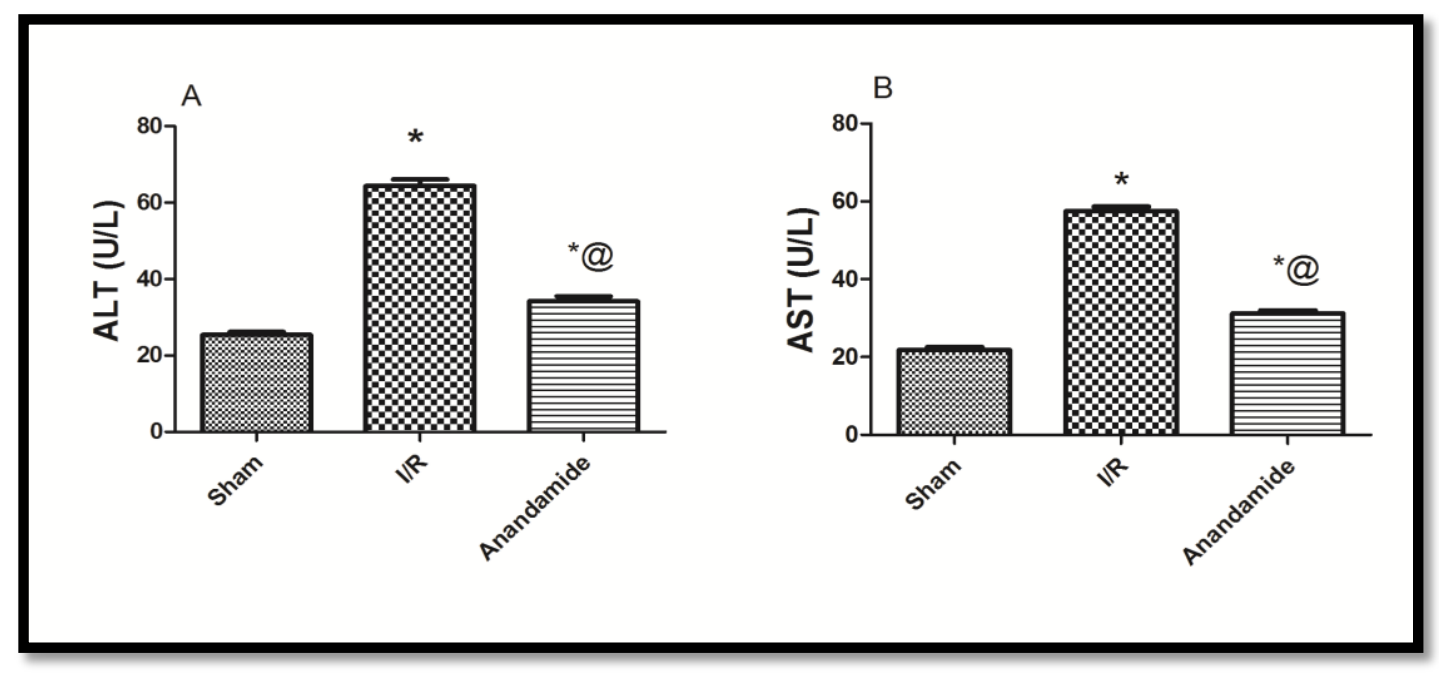

Figure (8): Effect of $30 \mathrm{~min}$. pre-administration of anandamide $(0.4 \mathrm{ml} / \mathrm{kg}$, i.p) on serum activities of (A) ALT and (B) AST of rats subjected to ischemia/reperfusion (I/R; 30/90 min.). Values are expressed as mean \pm SEM ( $n=8$ animals). Statistical analysis was carried out using one way ANOVA followed by Tukey's test for multiple comparisons. Significantly different from sham $(*)$ and I/R $\left({ }^{@}\right)$ control groups, $P<0.05$. 


\section{DISCUSSION}

I/R injury is an interruption of organ's blood flow with its subsequent lack of oxygen and nutrient supply followed by reflow of blood and oxygen supply ending in ATP depletion, loss of cell membrane integrity and cellular damage (SerracinoInglott et al., 2001; Romanque et al., 2005). In the current work and as a result to the I/Roverproduction of ROS and FRs, lipid peroxidation level was significantly increased in the tested organs, viz., the stomach and liver. Redox imbalance was further verified by the decrease in the assessed endogenous enzymatic antioxidants, such as SOD and CAT, as well as the nonenzymatic antioxidant GSH, leaving the present organs more vulnerable to the increased shower of ROS. The I/R-induced gastric injury was reflected by the increased ulcer index, an effect that can be explained by the inhibition of $\mathrm{NO}$ and the protective prostaglandins (Yusifzade et al., 2009).

In the present experimental study, the rats pretreated with anandamide exhibit a significant attenuation in the I/R-mediated oxidative stress in both stomach and liver. It lowered lipid peroxidation and enhanced the content of the endogenous enzymatic (SOD, $\mathrm{CAT})$ and non-enzymatic (GSH) antioxidant defense systems, to reach a normal level or even to exceed it, especially in the GSH content. Moreover, the anti-oxidant effect of anandamide was supported by other in-vitro (Jia et al., 2014) and in-vivo studies following testicular torsion (Beheshtian et al., 2008) and transient global cerebral ischemia (Zhang et al., 2009). The NADPHdependent oxidase (Nox) system is one source of ROS overproduction (Klcbanoff, 1988; Reilly et al., 1991). The Nox2, a subunit of Nox, contributes to oxidative damage of the tissues (Ano et al., 2010) and its inhibition can attenuate oxidative stress injury (Ha et al., 2010; Ye et al., 2012).
Another potential source of ROS production is neutrophils through the Nox system '(Weiss and Ward, 1982). In the present study, the I/R insult encouraged the infiltration of neutrophils as evidenced by the gastric and hepatic increase in their marker, MPO. Since the stomach is in a constant state of controlled inflammation, thus, amplification of the inflammatory response triggers pathological responses to I/R, beside the infiltration of the inflammatory cells, assessed as MPO. Former researchers have shown that induction of I/R stomach (Horie et al., 1997) increased the level of MPO in the affected organ, as well as the remote ones, findings that mimic the present results.

Upon injecting the rats with anandamide, it lowered the MPO level in both organs, pointing to its anti-inflammatory, as well as its anti-oxidant properties. The antineutrophil infiltration effect of anandamide may be attributed to its ability to activate the peroxisome proliferator-activated receptor- $\alpha$ dependent receptors (PPAR- $\alpha$ ), as reported by Alhouayek et al. (2014). These authors stated that increasing PPAR- $\alpha$ reduces neutrophils infiltration, an effect that may be partly responsible for the decreased oxidative stress. The anandamide-mediated inhibition of oxidative stress and neutrophil infiltration can explain the minimized gastric ulcer seen in the anandamide group, results that coincide with previous ones, pointing to its upregulating effect on $\mathrm{CB} 2$ protective receptors, in addition to reduce the mucosal oxidative stress (Warzecha et al., 2011).

In the present work, both TNF $\alpha$ and NF$\kappa \mathrm{B}$ were elevated in the two organs. TNF $\alpha$ is a signature cytokine of inflammation, where it triggers the activation of the $N F-\kappa B$ pathway, and in a vicious cycle pattern, the activated $\mathrm{NF}-\kappa \mathrm{B}$ signaling pathway results in the induction of TNF $\alpha$ as a downstream pathway (Sancho et al., 2003). Anandamide, in the present study, verified its antiinflammatory character by inhibiting the 
amount of TNF $\alpha$ and NF- $\kappa$ B. These findings coincide with that of previous studies, stating that anandamide decreases the level of TNFa (Rettori et al., 2012) and NF-kB (Sancho et al., 2003). The latter effect was attributed to the inhibition of TNF $\alpha$-mediated $N F-\kappa B$ activation via direct inhibition of the Ikappa $\beta$ kinase (IKK)- $\beta$ with the subsequent inhibition of $\mathrm{NF}-\kappa \mathrm{B}$ binding to DNA, lowering, thus, the NF- $\kappa \mathrm{B}$-dependent transcription. Furthermore, the study of Esposito and coworkers (2014) offered another explanation of the anandamide antiinflammatory effect through the involvement of the toll like receptor (TLR) pathway.

AMPK is a crucial regulator of energy metabolic homeostasis at the cellular and organismal survival during stress (Jing et al., 2013). Several studies have revealed a close link between the reduced AMPK activity and inflammation (Gauthier et al., 2011). Steinberg et al. (2006) observed that TNF- $\alpha$ suppressed the activity of AMPK by upregulating the expression of protein phosphatase 2C, an inhibitor of AMPK signaling (Bai et al., 2010). However, this was not the case in the present work, where I/R slightly increased the AMPK level, an effect that can be considered as a compensatory mechanism of the body against the I/R injury.

Administration of anandamide reversed the I/R action, as it elevated the AMPK by 4 folds and at the same time inhibited the inflammatory markers. There is emerging evidence that through its signaling network, AMPK can suppress the activation of NF- $\kappa B$ system indirectly, where $\mathrm{NF}-\kappa \mathrm{B}$ by itself is not a direct target of phosphorylation by AMPK; however, several downstream targets of AMPK, e.g., SIRT1, PGC-1 $\alpha$, p53, and Forkhead box $\mathrm{O}$ (FoxO) factors are responsible for inhibiting the NF- $\kappa \mathrm{B}$ signaling (Salminen et al., 2011). Moreover, AMPK is linked also to oxidative stresses as documented by the findings of the present work and by Salminen et al. (2011). In a previous study, Li et al. (2009) revealed that AMPK signaling induced the expression of mitochondrial uncoupling protein-2 (UCP-2), hence, reducing the production of superoxide radicals in hyperglycemic endothelial cells. Besides the AMPK-mediated induction UCP-2 protein, the production of ROS is inhibited by AMPK through suppression of the Nox system (Wang et al., 2010). In an interplay between AMPK, NF- $\mathrm{BB}$ and oxidative stress, Wang et al. (2010) stated that the mechanism whereby AMPK inhibits the $N F-\kappa B$ signaling involves the downregulation of different Nox subunits leading to the alleviation of oxidative stress, besides the anti-inflammatory action.

Several studies point to the injurious effect of intestinal $\mathrm{I} / \mathrm{R}$ on liver, which is considered the first distant organ affected by this insult (Towfigh et al., 2000) reported that the liver is, due to its coupled vasculature with the intestine, however, this is the first study to correlate the influence of gastric I/R on liver function. An ample of evidence reported that the liver is a major site for dysfunction after $I / R$ insult and this injury is coupled by a significant elevation of its aminotraferases viz., AST and ALT (Kurabayash et al., 2005; Harada et al., 2007; Trocha et al., 2014). These reports support the current findings, where the gastric I/R resulted in hepatic dysfunction manifested by elevation in both AST and ALT. Similar results were reported by many investigators using gut $\mathrm{I} / \mathrm{R}$. In the present investigation, the pretreated rats with anandamide hampered the $\mathrm{I} / \mathrm{R}$ effect on the measured aminotraferases, indicating a protective effect of anandamide mediated by its antioxidant and anti-inflammatory characters. In a recent study, Bátkai et al. (2012) supported the present findings, where anandamide, in their study also protected liver injury mediated by a hepatic I/R model 
by virtue of its antioxidant/anti-inflammatory characters.

In conclusion, the present study showed that gastric I/R-induced damage can entail remote organs as liver and that anandamide protected against this harmful effect by virtue of its antioxidant and anti-inflammatory characters.

\section{REFERENCES}

Agurell S, Halldin M, Lindgren JE, Ohlsson A, Widman M, Gillespie $\mathrm{H}$ and Hollister L(1986). Pharmacokinetics and metabolism of delta 1-tetrahydrocannabinol and other cannabinoids with emphasis on man. Pharmacol Rev. Mar; 38(1):21-43.

Ahmed, A.E., Hussein, G.I., Loth, J.P., and Abdel-Rahman, S.Z. (1991). Studies on the mechanism of haloacetnitrile-induced gastrointestinal toxicity: interaction of dihaloacetonitrile with glutathione and glutathione-S-transferase in rats. $J$ Biochem Toxicol, 6: 115-121.

Alhouayek M, Bottemanne P, Subramanian KV, Lambert DM, Makriyannis A, Cani PD and Muccioli GG (2014). NAcylethanolamine-hydrolyzing acid amidase inhibition.

Ano Y, Sakudo A, Kimata T, Uraki R, Sugiura $\mathrm{K}$ and Onodera T (2010). Oxidative damage to neurons caused by the induction of microglial NADPH oxidase in encephalomyocarditis virus infection. Neuroscience Letters. ;469(1):3943.

Bai A, Ma AG, Yong M, Weiss CR, Ma Y, Guan Q, Bernstein CN and Peng Z(2010). AMPK regulates innate and adaptive immune response in TNBS- induced murine acute and relapsing colitis. Biochem Pharmacol. Dec 1;80(11):1708-17

Balk RA (2000). Pathogenesis and management of multiple organ dysfunction or failure in severe sepsis and septic shock. Crit Care Clin 16: 337-352.

Bátkai S, Mukhopadhyay P, Horváth B, Rajesh $M$ and Gao RY (2012). $\Delta 8$ Tetrahydrocannabivarin prevents hepatic ischaemia/reperfusion injury by decreasing oxidative stress and inflammatory responses through cannabinoid CB2 receptors $\mathrm{Br} \quad J$ Pharmacol. 165(8):2450-2461

Beheshtian A, Salmasi AH, Payabvash S, Kiumehr Set et al., (2008). Role of endogenous cannabinoids in ischemia/reperfusion injury following testicular torsion in rats. Int $J$ Urol. May;15(5):449-54..

Bradley PP, Priebat DA, Christenen RD and Rothstein G (1982). Measurement of cutaneous inflammation: estimation of neutrophil content with an enzyme marker. J Invest Dermatol, 78: 206- 209.

Coruzzi G, Adami M, Coppelli G, Frati P and Soldani G (1999). Inhibitory effect of the cannabinoid receptor agonist WIN 55,212-2 on pentagastrin-induced gastric acid secretion in the anaesthetised rat. NaunynSchmiedebergs Arch. Pharmacol. 360:715718.

Cour M, Abrial M, Jahandiez V, Loufouat J, Belaïdi E, Gharib A, Thibault H, Ovize M and Argaud L (2014). Ubiquitous protective effects of cyclosporine $\mathrm{A}$ in preventing cardiac arrest-induced multiple organ failure. J Appl Physiol. Oct 15;117(8):930-6.

El-Abhar, H.S., Abdallah, D.M., and Saleh, S. (2003). Gastroprotective activity of Nigella sativa oil and its constituent, thymoquinone against gastric mucosal injury induced by ischaemia/reperfusion in rats. $\mathrm{J}$ Ethnopharmacol, 84: 251-258.

Esposito G, Capoccia E, Turco F, Palumbo I, Lu J, Steardo A, Cuomo R, Sarnelli G, Steardo L (2014). Palmitoylethanolamide improves colon inflammation through an 
enteric glia/toll like receptor 4-dependent PPAR- $\alpha$ activation. Gut. Aug;63(8):1300-12.

Gauthier MS, O'Brien EL, Bigornia S, Mott M , et al (2011). Decresed AMP- activated protein kinase activity is associated with increase inflammation in visceral adipose tissue and with whole- body insulin resistance in morbidly obese humans Biochem Biophys Res Commun. Jan 7;404(1):382-7.

Ha JS, Lim HM and Park SS (2010). Extracellular hydrogen peroxide contributes to oxidative glutamate toxicity Brain Res. Nov 4;1359:291-7.

Harada N, Okajima K, Kohmura H, Uchiba M and Tomita T (2007). Danaparoid sodium reduces ischemia/reperfusion-induced liver injury in rats by attenuating inflammatory responses. Thromb Haemost._Jan; 97(1):81-7.

Horie Y, Wolf R and Granger DN (1997). Role of nitric oxide in gut ischemia-reperfusion induced hepatic microvascular dysfunction. Am J Physiol 273: G1007-G1013.

Howlett AC, Barth F, Bonner, TI et al (2002). International Union of Pharmacology. XXVII. Classification of cannabinoid receptors. Jun;54(2):161-202.

Izzo AA, Fezza F, Capasso R, Bisogno T, Pinto $\mathrm{L}$, Iuvone $\mathrm{T}$, Esposito $\mathrm{G}$, Mascolo $\mathrm{N}$, Di Marzo V, Capasso F. (2001). Cannabinoid $\mathrm{CB}_{1}$-receptor mediated regulation of gastrointestinal motility in mice in a model of intestinal inflammation. $\mathrm{Br} J$ Pharmacol. 134(3):563-570.

Jia J, Ma L, Wu M, Zhang L, Zhang X, Zhai Q, Jiang T et,al (2014). Anandamide Protects HT22 Cells Exposed to Hydrogen Peroxide by Inhibiting $\mathrm{CB}_{1}$ Receptor-Mediated Type 2 NADPH Oxidase Oxid Med Cell Longe. july 10.1155/2014/893516

Jing, Yao, Liu, Fan, Zhang, Li, et al (2013). Fish-oil emulsion (omega-3 polyunsaturated fatty acids) attenuates acute lung injury induced by intestinal ischemia-reperfusion through Adenosine 5'-monophosphateactivated protein kinase-sirtuin1 pathway. $J$ Surg Res. Sep 26;11(1):167.

Klcbanoff, S.J. (1988). Phagocytic cells: products of oxygen metabolism. In: "Inflammation: basic principles and clinical correlates." Eds., J.I. Gallin, I.M. Goldstein \& R. Snyder, Raven Press, New York, pp. 391-444.

Kotani, T., Murashima, Y., Kobata, A., Amagase, K., and Takeuchi, K. (2007). Pathogenic importance of pepsin in ischemia/reperfusion -induced gastric injury. Life Sci, 80: 1984 -1992.

Kurabayashi M, Takeyoshi I, Yoshinari D, Matsumoto K, Maruyama I and Morishita Y (2005). 2-Arachidonoylglycerol increases in ischemia-reperfusion injury of the rat liver. J Invest Surg. Jan-Feb;18(1):25-31.

Li XN, Song J, Zhang L, LeMaire SA, Hou X, Zhang C, Coselli JS, Chen L, Wang XL, Zhang Y, Shen YH (2009). Activation of the AMPK-FOXO3 pathway reduces fatty acidinduced increase in intracellular reactive oxygen species by upregulating thioredoxin. Diabetes; 58(10):2246-57.

Marklund, S., and Marklund, D. (1974). Involvement of the superoxide anion radical in the autoxidation of pyrogallol and a convenient assay for superoxide dismutase. Eur J Biochem, 47: 469-470.

Mihara, M., and Uchiyama, M. (1978). Determination of malonaldehyde precursor in tissues by thiobarbituric acid test. Annual Biochem, 86: 271- 278.

Nishida, K., Ohta, Y., and Ishiguro, I. (1998). Relation of inducible nitric oxide synthase activity to lipid peroxidation and non-protein sulfhydryl oxidation in the development of stress-induced gastric mucosal lesions in rats. Nitric Oxide, 2: 215-223. 
Reilly, M.P., Schiller, H.J., and Bulkley, G.B. (1991). Pharmacologic approach to tissue injury mediated by free radicals and other reactive oxygen metabolites. Am J Surg, 161: 488-503.

Rettori E, De Laurentiis A, Zorrilla Zubilete M, Rettori V and Elverdin JC (2012). Antiinflammatory effect of the endocannabinoid anandamide in experimental periodontitis and stress in the rat Neuroimmunomodulation. 19(5):293-303

Romanque, P., Uribe, M., and Videla, L.A. (2005). Molecular mechanisms in liver ischemic-reperfusion injury and ischemic preconditioning. Rev Méd Chile, 133: 469476.

Salminen A and Kaarniranta K (2011). Control of p53 and NF- $\kappa \mathrm{B}$ signaling by WIP1 and MIF: role in cellular senescence and organismal aging. Cell Signal 23:747-752.

Sancho R, Calzado MA, Di Marzo V, Appendino G and Muñoz E (2003). Anandamide inhibits nuclear factor-

kappaB activation through cannabinoid receptor in dependent pathway. Mol Pharmacol. Feb;63(2):429-38..

Serracino-Inglott, F., Habib, N.A., and vMathie, R.T. (2001). Hepatic ischemia-reperfusion injury. Am J Surg, 181: 160-166.

Seyyed Ali M, Neisi N, Darbor M, Hassanpour M, Makvandi M and Solgi G (2012). $\beta$ carotene protects the gastric mucosa against ischemia-reperfusion injury in rats. Eur Cytokine Netw. 2012 Oct-Dec; 23(4):173-8.

Sofia RD, Diamantis W, Harrison JE and Melton J (1978). Evaluation of Antiulcer Activity of $\Delta^{9}$-Tetrahydrocannabinol in the Shay Rat Test. 17(3): 173-177

Steinberg GR, Michell BJ, van Denderen BJW, Watt MJ et al (2006). Tumor necrosis factor $\alpha$-induced skeletal muscle insulin resistance involves suppression of AMP-kinase signaling. Cell Metab Dec;4(6):465-74.

Gren green The Cannabis Breeder's Bible, Green Candy Press, 2005, pp. 15-16.

Towfigh S, Heisler T, Rigberg DA, Hines OJ, Chu J, McFadden DW, et al. (2000). Intestinal ischemia and the gut-liver axis: an in vitro model. J Surg Res 88: 160-164.

Trocha M, Merwid-Ląd A, Chlebda E, Sozański T , Pieśniewska $M$ et al (2014). Influence of ezetimibe on selected parameters of oxidative stress in rat liver subjected to ischemia/reperfusion. Arch Med Sci. Aug 29; 10(4):817-24.

Turnage RH, Bagnasco J, Berger J, Guice KS, Oldham KT and Hinshaw DB (1991). Hepatocellular oxidant stress following intestinal ischemia-reperfusion injury. J Surg Res 51: 467471.

Warzecha Z, Dembinski A, Ceranowicz P, Dembinski M et al (2011). Role of sensory nerves in gastroprotective effect of anandamide in rats. $J$ Physiol Pharmacol. Apr;62(2):207-17.

Weiss SJ and Ward PA (1982). Immune complex induced generation of oxygen metabolites by human neutrophils. J Immunol 129: 309-313.

YeQ, HuangB, ZhangX, ZhuY and ChenX (2012). Astaxanthin protects against MPP+induced oxidative stress in PC12 cells via the HO-1/NOX2 axis. BMC Neuroscience. . Dec 29;13:156

Yusifzade K , Akin M, Isikgonul I, Gulbahar O, Anadol AZ et al (2009). The protective role of anandamide in mesenteric ischemia reperfusion injury in guinea pig. Bratisl Lek Listy. ;110(7):379-84..

Zhang YB, Kan MY, Yang ZH, Ding WL, Yi J, et al (2009). Neuroprotective effects of Nstearoyltyrosine on transient global cerebral ischemia in gerbils. Brain Res. Sep 1;1287:14656. 


\section{الاناتداميد يقوم بتخفيف القرحه وتغيير الالتهاب وعوامل الاكسده الاجهاديه المحدثه بالقصور

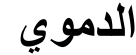 \\ حسن محمد شحاته , حنان صلاح الدين الابحر , نبيله نور الاين المراغي قسم الفارماكولوجي, كليه الصيلدله, جامعه 6 اكتوبر}

الانانداميد هو ناهض مستقبلات القنب الذب أظهر وجود تأثثر وقائي ضد قصور الامداد الدموي في الامعاء ـ. مع ذلك ،الأثر التغييري على قرحة المعدة الناجم عن قصور الامداد الدموي لم يتم توضيحها سابقا. لذاللك ، كان الهدف من هذه الدراسةهو لتحديد هذا الأثر تغييري من الانانداميد على قرحة المعدة و احتمال تورط الكبد. تم اختيار الفئران بصورة عشو ائية في الثام ، مجموعه قصور الامداد الدموي و مجموعة المعالجة با الانانداميد ( 11.5 mmo / كغ ) ـ قصور الامداد الدموي في المعدة تسبب زيادة في مؤشر قرحة المعدة ، بالإضافة إلى ارتفاع وسائط الالتهابات مثل:عامل نخر الورم ألفا, العامل النووي كابا بي و انزيم ميالوبير أوكسيديز جنبا إلى جنب مع انخفاض ملحوظ في نشاط أدينوزين مونو فوسفات بروتين كايناز ؛ وقد ظهر هذا التأثير سواء في المعدة و الكبد. علاوة على ذلك فإن تدمير المعدة أدى الى حدوث خلل في نظام الأكسدة و الاختزال ، حيث ارتقى محتوى الدهون المؤكسة مع انخفاض ملحوظ في نظام الدفاع(السوبر اوكسيد ديسميوتيزز, الكاتلاز و الجلوتاثيون).بالإضافة إلى ذلك ، قصور الامداد الدموي تسبب زيادة ملحوظة في نشاط أنزيمات الكبد مثل: أسبرتات أمينو ترانسفيراز (AST) و الألنين أمينو تر انسفير از) (ALT) وهذا دليل توثيقي على تأثر الكبد بنوذج قصور الامداد الدموي المحدث

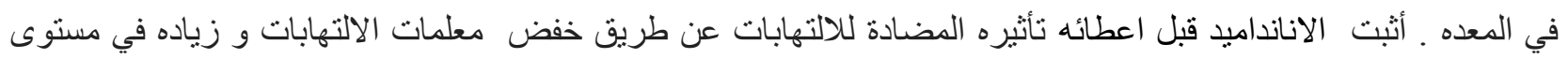
أدينوزين مونو فوسفات بروتين كايناز بالاضافه الى ذاللك وجود زياده في مستوى الانزيمات المضاده للاكسده مثل: السوبر اوكسيد ديسميوتيزز, الكاتلاز و الجلوتاثيون جنب الى جنب مع ارجاع ال (إم دي إيه)الى المستوى الطبيعي. تتلخص هذه الدر اسه في ان الاليات الوقائيه لماده الانانداميد لقرحه المعده الناجمه عن قصور الامداد الدموي و إصـابة الكبد قد تكون بوساطه تعديل الاكسدة من خلال تحسين نظام الدفاع الذاتية. بالإضافة إلى ذلك ، فإن التأثير المضاد للالتهابات لماده الانانداميد قد يتيسر عن طريق مسار ات الادينوزين مونو فوسفات بروتين كايناز و العامل النووي كابا بي. 